\title{
KUERS
}

1958

DEEL XXVI

NOMMER EEN

\section{KWARTEEU JUBILEUM}

D

IE blad in sy nuwe vorm stel hom op die grondslag van die Heilige Skrif ... . Dit wil die beginsels van die Heilige Skrif volgens die interpretasie van die Calvinisme propageer op alle terreine van die lewe." Met hierdie ondubbelsinnige beleidsverklaring $h$ et Koers vyf-en-twintig jaar gelede vir die eerste keer as tweemaandelikse tydskrif verskyn. Getrou aan die verhewe doelstelling het die blad nou vir 'n kwarteeu 'n helder lig versprei oor 'n groot verskeidenheid van vraagstukke en ongetwyfeld ' $n$ positiewe bydrae gelewer tot bestendiging en uitbouing van die Calvinistiese grondslag van die Afrikaanse kulturele lewe.

Wie deur die uitgawes van Koers vanaf die eerste in Augustus 1933 tot die jongste in Junie 1958 blaai kom diep onder die indruk van die konstantheid waarmee die verskillende probleme in akademiese kringe sowel as in die volkslewe deurtastend en waarheidsgetrou ontleed is. 'n Mens sou graag die geldigheid van hierdie stelling wou bewys deur 'n inhoudsopgawe van alle nommers te gee; dit is natuurlik onmoontlik, maar let op die inhoud van die eerste nom- mer: J. A. du Plessis: Die betekenis van die Afrikaanse bybel vir ons; A. J. H. van der Walt: Soewereine onafhanklikheid en koalisie; D. J. van Rooy: C.N.O.; L. J. du Plessis: Die Krisis in die demokrasie; A. P. Goossens: Droogte en die natuurlike bodembedekking; J. Chris Coetzee: Die godsdiens van die kleuter.

Tewens, ek verstout my om te sê dat Koers 'n unieke blad in Suid-Afrika (en miskien ook nog in wyer kring) is om so 'n verskeidenheid van leesstof op wetenskaplike peil oor so 'n lang tydperk aan te gebied het. Dit is die roem van die geloof en visie van die oorspronklike stigters!

Vyf-en-twintig jaar is die formele lewensduur van 'n geslag. Koers het dus op sy beskeie manier in diens van die Afrikaanse volk en Christelike wetenskap reeds vir een reslag gestaan. Dit is ' $n$ voorreg en 'n prestasie. Maar ewe-eens is dit ' $n$ voorreg en genadedaad van God dat die meeste van die oorspronklike stigters en drie van die vier lede van die eerste redaksie nog in lewe en aktief is en ' $n$ bydrae tot hierdie uitgawe kon lewer. Die huidige redaksie beskou dit as ' $n$ besondere aangeleentheid en wil graag langs hierdie weg 'n eresaluut bring aan die stigters en redaksielede uit die ,vorige geslag." 
Die feit dat een van die oorspronklike stigters en vroegste redaksielede tans nog op die redaksie as ondervoorsitter kan dien verskaf veel genoeë. Ek verwys na prof. L. J. du Plessis wat van Desember 1933 tot Oktober 1937 op die redaksie was en weer vanaf 1955 as ondervoorsitter. Sy raad is waardevol en word met die hoogste agting bejeen.

Aan prof. J. Chris Coetzee wat vir negentien van die vyf-en-twintig jaar hoofredakteur was en vir nog twee jaar op die redaksie gedien het ' $n$ besondere woord van dank en hoogste lof. Dit is 'n prestasie wat moeilik ge-ewenaar of oortref sal word. Die name van drie ander staatmakers op die redaksie gedurende die kwarteeu mag nie verswyg word nie: Prof. D. J. van Rooy, vanaf die stigting vir tien jaar lank sekretaris, prof. H. G. Stoker, lank redaksielid en vir drie jaar lank hoofredakteur en prof. S. du Toit vir veertien jaar lank lid van die redaksie. Die onselfsugtige diens van al bogenoemde persone is verbysterend en hulle blywende belangstelling word deur hierdie uitgawe bewys.

Laastens moet ons hulde betuig aan almal wat op die redaksie of direksie gedien het, en aan alle lede, intekenaars en ondersteuners wat hulle geloof in die geestelike bouwerk van Koers met die daad onderskraag het.

Maar nou die hede en die toekoms. Met hierdie uitgawe word nog 'n mylpaal bereik! Koers is nou 'n maandblad!
Dit is ' $n$ moedige daad, want die weg sal nie met rose besaai wees nie. Dit is egter die oortuiging van die lede en die redaksie dat 'n maandblad noodsaaklik geword het vir die doeltreffender bevordering van ons doelwit om Koers te laat ontwikkel as 'n mondstuk van Calvinistiese denke. Ons vertrou dat dit algemene byval sal vind en dat ons kan staatmaak op daadwerklike ondersteuning.

Behalwe die gewone artikels bied die redaksie 'n paar nuwe rubrieke aan met die verwagting dat dit wye belangstelling sal erlang; 'n rubriek vir Christelike opvoeding; 'n vaste rubriek vir die teologiese wetenskap vanuit Gereformeerde beginsels; (prof. W. J. Snyman sal onder andere eersdaags met 'n reeks eksegetiese studies begin); 'n rubriek vir prinsipiële kommentaar oor belangrike binne- en buitelandse gebeurtenisse; 'n rubriek vir diskussie oor artikels of aspekte daarvan. Lesers en Calvinistiese skrywers word hartlik uitgenooi om van Koers gebruik te maak as mondstuk van hulle wetenskaplike denke en studie. Koers wil ook graag die kanaal wees waarlangs oorspronklike navorsing aan die buitewêreld bekend gestel word.

Op die skof van die tweede kwarteeu bied die redaksie met volle vertroue en hoë verwagtings Koers aan as maandblad ter bevordering van die Christelike denke en lewenstradisie in Suid-Afrika.

W. N. COETZEE. 